\title{
Outcome of prenatally diagnosed central nervous system malformations in a tertiary center in Singapore
}

\author{
Geetha $\mathrm{O}^{1}$, Chandran $\mathrm{S}^{2}$, Sriram B ${ }^{3}$, George Y. S. $\mathrm{H}^{4}$, Gomez J. $\mathrm{M}^{5}$, Rajadurai V. $\mathrm{S}^{6}$ \\ ${ }^{1}$ Dr. Odattil Geetha, Associate Consultant, Department of Neonatology, ${ }^{2}$ Dr. Suresh Chandran, Senior Consultant, \\ Department of Neonatology, ${ }^{3}$ Dr. Bhavani Sriram, Visiting Senior Consultant, Department of Neonatology, ${ }^{4}$ Professor \\ Yeo Seow Heong, George, Head of Department and Senior Consultant, Department of Maternal Fetal Medicine, \\ ${ }^{5}$ Dr Joseph Manuel Gomez, Head of NICU and Senior Consultant, Department of Neonatology, ${ }^{6}$ Professor Victor \\ Samuel Rajadurai, Head of Department and Senior Consultant, Department of Neonatology; all authors are attached with \\ KK Women's and Children's Hospital, Singapore.
}

Address for Correspondence: Dr. Odattil Geetha, Associate Consultant, Department of Neonatology, KK Women's and Children’s Hospital, 100 Bukit Timah Road, Singapore. Email: odattil.geetha@ singhealth.com.sg

\begin{abstract}
Background: Central nervous malformations are associated with major morbidity and mortality in infants and children. Knowledge of the data about their outcome and neurodisability will help in perinatal counseling and aid in parental decision-making. Objective: To study the fetal and neonatal characteristics of prenatally diagnosed central nervous system (CNS) malformations and the neurodevelopmental outcome of the survivors over 5years. Methods: Maternal and neonatal records of prenatally diagnosed CNS malformations were retrospectively reviewed over five years (January 2005 till December 2009). The relevant fetal and neonatal data were collected from the database maintained by the birth defect registry. The long-term neurodevelopment data was obtained from case records. Results: There were 116 cases of fetal structural CNS malformations. Termination of pregnancy or fetal deaths occurred in 80/116 (69\%) of cases, of which 68\% had Neural tube defects (NTD). There were 36 live births, of which six infants died of anencephaly and were not included in the study. Among 30 live births 17\% of infants needed ventilator support and $17 \%$ had neurosurgical intervention. On follow up 37\% of the cohort had neurodevelopmental delay, $10 \%$ died, $30 \%$ had normal neurodevelopmental outcome and $23 \%$ defaulted on follow-up. Conclusions: In two-thirds of the fetuses of prenatally diagnosed CNS malformations, termination of pregnancy or fetal death occurred. Nearly half of the survivors who were followed up had a composite outcome of death or global neurodevelopmental delay and need for support services.
\end{abstract}

Keywords: Central nervous system malformation, Congenital anomalies, Global developmental delay, Termination of pregnancy, Neural tube defects.

\section{Introduction}

Fetal anomalies are recognized as one of the leading causes of morbidity and mortality among infants and children [1]. Two percent of all fetuses and infants are reported to have major congenital malformations [2]. Developmental insults during early embryological growth can lead to developmental disabilities later in life. The cognitive, motor, and sensory deficits seen in late childhood correlate to the type and numbers of major birth defects [3]. Accurate prenatal diagnosis of fetal anomalies allows parents to assess the immediate

Manuscript received: $4^{\text {th }}$ July 2016

Reviewed: $14^{\text {th }}$ July 2016

Author Corrected; $26^{\text {th }}$ July 2016

Accepted for Publication: $12^{\text {th }}$ August 2016 and long-term implications of congenital abnormalities, and in turn to make an informed decision on continuing the pregnancy $[4,5]$. Additionally, prenatal diagnosis enables parents to assess the recurrence risk of having a baby with congenital malformations. Today, with the state of the art technology in early fetal anomaly detection, parents can have appropriate counseling by a multidisciplinary team to reduce apprehension. Families can thus understand the situation better in order to make timely appropriate decisions $[6,7]$.

Among cases of isolated congenital anomalies at birth, CNS anomalies account for nearly $9 \%$. Nearly $16 \%$ of infants with multiple malformations have CNS defects, 
making cranial malformations a major concern in antenatal diagnosis [8]. Many of the major anomalies can be diagnosed by antenatal ultrasonography (US), the basic screening examination for pregnant woman.

However with antenatal US, subtle abnormalities especially in posterior cranial fossa, can go undetected, or can only be detected in the later stages of pregnancy $[9,10]$. Fetal magnetic resonance imaging (MRI) is a more effective imaging tool, which is recommended when there is a diagnostic dilemma, or when a more detailed study of fetal brain is required $[11,12]$.

Many studies have shown that most major CNS anomalies result in devastating effects on the developing brain [13, 14, 15]. However, long-term follow-up studies of infants born with CNS malformations are lacking. This study aims to examine the prevalence of major congenital CNS malformations and their outcome over five years.

\section{Materials and Methods}

The study was conducted at KK Women's and Children's Hospital, which is the largest tertiary referral center in Singapore for high-risk pregnancies, fetal imaging, prenatal diagnosis and intervention.

Maternal and neonatal records of prenatally diagnosed CNS malformations in babies were retrospectively reviewed over a five-year period from January 2005 to December 2009. Retrieval of relevant fetal and neonatal data was done from the Birth Defects Registry's database, which compiles prospectively collected data of mothers who carried fetuses with birth defects.

The data collected includes maternal demographics such as age, race, associated fetal malformations, cytogenetic analysis, and Termination of pregnancy (TOP). For the live births, data was gathered from the case records using a standardized data collection form.

Besides maternal demographics, data collection included perinatal and neonatal outcomes, surgical methods and their outcomes, and long-term neurodevelopmental status over five years.
Routine dating scans are performed before 14 weeks of gestation, a screening scan at 20 weeks gestation, and a growth scan is performed in the third trimester in our institution. Accredited sonographers perform detailed antenatal scan and in the presence of structural malformations maternal-fetal specialists will verify the images. The mother would also be offered the option to undergo amniocentesis and cytogenetic analysis. A multidisciplinary team comprising feto-maternal physicians, neonatologists, geneticists, ultrasonographers, radiologists, surgeons, neurologist, and cardiologist, meet on a weekly basis to discuss the cases with the birth defects and suggest appropriate plans.

Fetal MRI was performed for structural CNS malformations when there were diagnostic challenges. Once a fetal CNS anomaly was diagnosed, the appropriate multidisciplinary team would counsel parents. The discussion will focus on the antenatal findings and the postnatal outcomes and the need for long-term neurodevelopmental follow up. Postnatally, the neonate will be clinically assessed and evaluated and would undergo appropriate imaging.

The clinical examination and investigations were performed according to the unit protocol and cytogenetic studies were offered for malformations. Post discharge, the neonatologist; neurologist, and the early intervention program team will follow up the infant. The team would monitor the infant's physical growth and development, visual and hearing outcomes, identify intervention required for babies with neurodevelopmental delays, and where necessary, recommend special school placement for early intervention services.

Clinicians who followed up these children used Denver II Developmental Screening Test (DDST). Cerebral Palsy was diagnosed by the neurologist using the Gross Motor Function Classification System (GMFCS). The term global developmental delay (GDD) is used to describe developmental disability in children with significant delay in at least two of the major domains of development: gross and fine motor, speech and language, cognition, social and personal development and activities of daily living.

\section{Results}

During this five-year period, we identified 116 structural CNS malformations (Table 1). Eighty (69\%) cases underwent TOP and fetal deaths. There were 36/116 (31\%) live births. 
Table-1: Antenatally Detected Central Nervous System Malformations.

\begin{tabular}{|c|c|}
\hline Central Nervous System & Number (\%) \\
\hline Total no of cases with antenatal CNS malformations & $\mathbf{1 1 6}$ \\
\hline No of cases that underwent TOP and fetal deaths & $\mathbf{8 0}$ \\
\hline Neural tube defects & $54(68 \%)$ \\
\hline Holoprosencephaly & $7((9 \%)$ \\
\hline Agenesis of corpus callosum & $4(5 \%)$ \\
\hline Cerebellar malformations & $6(8 \%)$ \\
\hline Posterior fossa cyst & $5(6 \%)$ \\
\hline Miscellaneous & $4(5 \%)$ \\
\hline No of live births with antenatal CNS malformations & $\mathbf{3 6}$ \\
\hline Neural tube defects & $9(25 \%)$ \\
\hline Holoprosencephaly & $3(8 \%)$ \\
\hline Hydrocephalus+hydranencephaly & $3(8 \%)$ \\
\hline Agenesis of corpus callosum & $7(19 \%)$ \\
\hline Cerebellar malformations & $3(8 \%)$ \\
\hline Posterior fossa cyst & $6(17 \%)$ \\
\hline Schizencephaly & $2(5 \%)$ \\
\hline Cerebral tumour & $1(3 \%)$ \\
\hline Porencephalic cyst & $1(3 \%)$ \\
\hline Hypoechoeic lesion & $1(3 \%)$ \\
\hline
\end{tabular}

Neural tube defects accounted for 54/80 (68\%) cases of TOP and fetal deaths, of which $37 / 54(68 \%)$ had anencephaly and $17 / 54$ had other NTD other than anencephaly. Holoprosencephaly accounted for 7/80 (9\%) of cases of which $57 \%$ had major associated congenital malformations including exomphalos major (2), trisomy 18 (1) and trisomy 13 (1). There were 4/80 (5\%) cases of agenesis of corpus callosum (ACC) with major associated malformations in two of them. One had a hypoplastic left heart syndrome and the other had trisomy18. There were $6 / 80(8 \%)$ cases of cerebellar malformations. Two of them had small cerebellum and absent cavum, 2 had absent inferior vermis and 2 had prominent gap in the vermis. In the 2 fetuses that had prominent gap in the vermis, one had associated hydrops fetalis with horseshoe kidneys and had 45XO in karyotype analysis whereas the other fetus had trisomy 13 with double outlet right ventricle. There were 5/80 (6\%) cases of posterior fossa cysts of which 3 had Dandy- Walker malformations. Two had associated malformations in the form of echogenic-enlarged kidneys and cardiac malformation with single outflow tract respectively. The karyotype was Trisomy 3 and Trisomy 9 respectively.

Amniocentesis for cytogenetic analysis was performed in 11/80 (14\%) mothers who had TOP or fetal death. Of those who underwent amniocentesis, 3 each of trisomy 18 and trisomy 13, one each of 45XO, trisomy 3 and trisomy 9 and the rest had normal karyotype.

Postmortem studies of fetuses terminated or had fetal death- Post-mortem (PM) evaluation was done in $13 / 80$ (16\%) cases. There were 11 cases $(85 \%)$ where PM findings correlated well with antenatal imaging report. Postmortem was performed in $8 / 17(47 \%)$ cases of NTD (excluding anencephaly), which had good concordance with the prenatal ultrasound study. Of the antenatally detected cases, one case of holoprosencephaly, Dandy-Walker malformation and cerebellar hypoplasia, each had PM study and confirmed the prenatal US findings. PM findings had discordance in two cases, of which one infant was suspected to have microcephaly and a small cerebellum in prenatal scan and PM report showed a vascular event with anoxic encephalopathy with neuronal loss. In the second case, the prenatal scan suggested septo-optic dysplasia and the PM showed lobar holoprosencephaly with septo-optic dysplasia.

Neonatal outcomes- There were 36 live births, of which 6/36 (16\%) infants were anencephalic and all of them died and were excluded from the study. Rest of the infants with CNS malformations was followed up for five years. The mean gestational age at screening was $25.8 \pm 7.5$ weeks. The mean birth weight and the mean gestational age of this cohort were $2.77 \pm 0.7 \mathrm{~kg}$ and $37.2 \pm 7$ weeks respectively. None of the infants in this cohort needed active resuscitation in the 
form of intubation and ventilation. Six (20\%) infants were born preterm, 4 were between $32-34$ weeks and 2 were 35 weeks of gestation. A total of 9/30 (30\%) infants underwent neurosurgical intervention, of which 6/9 (66\%) in the first week of life and 3/9 (33\%) in late infancy. Neurosurgical procedures included repair of myelomeningocele and ventriculo-peritoneal (VP) shunt insertion in 2/9 (22\%), while 6/9 (67\%) among them had VP shunt insertions alone and one infant had occipital encephalocoele repair.

Cytogenetic study in live born infants with prenatally detected CNS malformations- Of the 30 cases, antenatal cytogenetic study was performed in 5/30 (16\%), while postnatal cytogenetic study was performed in 4/30 (13\%). One fetus had triple $\mathrm{X}$ syndrome in the antenatal study group and four were normal. In the postnatal cytogenetic study group only one infant had abnormal karyotype. This was a trisomy 18 infant born to a 28 -year-old mother who refused prenatal karyotyping.

Table- 2: Survival Outcomes of The 11 children with global developmental delay over five years.

\begin{tabular}{|c|c|c|c|c|c|c|c|}
\hline S/Nc & $\begin{array}{l}\text { Gestation } \\
\text { age at } \\
\text { diagnosis } \\
\text { (weeks) }\end{array}$ & Diagnosis at birth & $\begin{array}{c}\text { Surgical } \\
\text { interven } \\
\text { tion } \\
\text { (Day of } \\
\text { life) }\end{array}$ & $\begin{array}{c}\text { Age at } \\
\text { follow up }\end{array}$ & $\begin{array}{c}\text { Cognitive } \\
\text { disabilities }\end{array}$ & $\begin{array}{c}\text { Motor } \\
\text { disabilities }\end{array}$ & $\begin{array}{c}\text { Other } \\
\text { disabilities }\end{array}$ \\
\hline 1 & 24 & $\begin{array}{l}\text { Hydrocephalus with } \\
\text { Arnold chiari } \\
\text { malformation }\end{array}$ & 2 & $\begin{array}{c}\text { Died at } 9.5 \\
\text { years }\end{array}$ & $\begin{array}{c}\text { Attended } \\
\text { special school } \\
\text { GDD }\end{array}$ & $\begin{array}{c}\text { Paraplegic, } \\
\text { non-ambulant }\end{array}$ & Nil \\
\hline 2 & 34 & $\begin{array}{l}\text { Hydrocephalus with } \\
\text { Arnold chiari } \\
\text { malformation }\end{array}$ & 2 & 5 years & $\begin{array}{c}\text { Attends } \\
\text { special school } \\
\text { GDD }\end{array}$ & $\begin{array}{l}\text { Walks with } \\
\text { frames- } \\
\text { paraplegic- }\end{array}$ & $\begin{array}{c}\text { Right } \\
\text { dislocated } \\
\text { hip, central } \\
\text { hypoventilati } \\
\text { on syndrome }\end{array}$ \\
\hline 3 & 22 & $\begin{array}{c}\text { Hemilobar } \\
\text { holoprosencephaly }\end{array}$ & - & 5 years & $\begin{array}{c}\text { Attends } \\
\text { special school } \\
\text { GDD }\end{array}$ & $\begin{array}{c}\text { Walks with } \\
\text { unsteady gait }\end{array}$ & \\
\hline 4 & 18 & $\begin{array}{c}\text { Severe holoprosencephaly } \\
\text { with a large single } \\
\text { monoventricle }\end{array}$ & 2 & 9 years & $\begin{array}{c}\text { Attends } \\
\text { special school } \\
\text { GDD }\end{array}$ & Non-ambulant & $\begin{array}{l}\text { Gastrostomy } \\
\text { feeds }\end{array}$ \\
\hline 5 & 31 & $\begin{array}{l}\text { Bilateral open-lip } \\
\text { schizencephaly }\end{array}$ & - & 7 years & $\begin{array}{c}\text { Attends } \\
\text { special } \\
\text { school,GDD }\end{array}$ & $\begin{array}{c}\text { Non-ambulant } \\
\text { with global } \\
\text { developmental } \\
\text { delay. }\end{array}$ & $\begin{array}{c}\text { Blind, } \\
\text { subluxated } \\
\text { hips }\end{array}$ \\
\hline 6 & 33 & $\begin{array}{l}\text { Bilateral open lip, } \\
\text { schizencephaly with } \\
\text { absent copus callosum } \\
\text { and absent septum }\end{array}$ & $\begin{array}{c}\text { Yes } \\
\text { at } 47 \\
\text { days old }\end{array}$ & 10 years & $\begin{array}{c}\text { Attends } \\
\text { special school } \\
\text { GDD }\end{array}$ & $\begin{array}{c}\text { Non-ambulant } \\
\text { with CP }\end{array}$ & Seizures \\
\hline 7 & 34 & Hydrocephalus & $\begin{array}{c}\text { At } 5 \\
\text { months }\end{array}$ & $\begin{array}{l}1.5 \text { years and } \\
\text { lost to follow } \\
\text { up }\end{array}$ & GDD & $\begin{array}{c}\text { Non-ambulant- } \\
\text { quadriplegic } \\
\text { CP }\end{array}$ & Blind \\
\hline 8 & 28 & Hydranencephaly & $\begin{array}{c}\text { At } 4 \\
\text { months }\end{array}$ & $\begin{array}{l}5 \text { years } 10 \\
\text { months }\end{array}$ & $\begin{array}{c}\text { Attends } \\
\text { special school } \\
\text { GDD }\end{array}$ & $\begin{array}{c}\text { Non-ambulant } \\
\text { Quadriplegic } \\
\text { CP }\end{array}$ & Blind, deaf \\
\hline 9 & 20.7 & $\begin{array}{c}\text { DW malformation, } \\
\text { suspected encephalocele }\end{array}$ & 2 & $\begin{array}{c}\text { Died at } 5.5 \\
\text { years }\end{array}$ & GDD & & \\
\hline 10 & 25.7 & $\begin{array}{l}\text { Large cisterna magna, } \\
\text { DW variant, Joubert } \\
\text { syndrome }\end{array}$ & - & $\begin{array}{l}\text { Seen at } 9 \\
\text { years }\end{array}$ & $\begin{array}{l}\text { Attends } \\
\text { special school } \\
\text { GDD }\end{array}$ & $\begin{array}{l}\text { Walks few } \\
\text { steps. }\end{array}$ & Ptosis \\
\hline 11 & 20.1 & $\begin{array}{c}\text { Gap in inferior vermis and } \\
\text { calcification of } \\
\text { periventricular area }\end{array}$ & - & 6 years & $\begin{array}{c}\text { Attends } \\
\text { special school } \\
\text { GDD }\end{array}$ & Able to walk & $\begin{array}{l}\text { Congenital } \\
\text { rubella } \\
\text { syndrome }\end{array}$ \\
\hline
\end{tabular}


Neuroimaging-Fetal MRI was performed in 8/30 (27\%) infants who had prenatal US detected CNS malformations. Fetal MRI confirmed schizencephaly in one infant and ACC in another.

Fetal MRI aided diagnosis in two more infants. One was a suspected case of Dandy-Walker malformation in fetal US, but MRI confirmed it to be a posterior fossa cyst.

Antenatal US showed septo-optic dysplasia but fetal MRI confirmed it as absent cavum septum pellucidum in one case. Fetal MRI confirmed a porencephalic cyst in another case where US diagnosis favored an intracerebral cyst in the left temporal region. All infants had postnatal US studies. Postnatal MRI was performed in 15/30 (50\%) infants.

Neurodevelopmental outcome and mortality- The five-year neurodevelopmental outcome revealed 11/30 (37\%) children with global developmental delay and they had moderate to severe neuro-disability. Table 2 lists the neurodevelopmental outcomes of these infants with severe neurodevelopmental impairment. Three cases (10\%) died during this 5-year period, 9/30 (30\%) children had normal development and 7/30 (23\%) defaulted follow up.

Of the three cases of NTD excluding anencephaly one had occipital encephalocele, which was repaired in the neonatal period but defaulted, follow up. The other two had Arnold-Chiari malformation and needed multiple admissions for shunt infection. There were 3 cases of holoprosencephaly of which one had VP shunt insertion and multiple admissions for shunt revision. One of them had absent cavum septum pellucidum in antenatal US but postnatal MRI had additional diagnosis of heterotopic grey matter in the parietal and perisylvian areas, suggesting a neuronal migration disorder.

The infant had normal growth and development and was followed up to 2 years of age, after which he was lost to follow up. In the hydrocephalus group of three, one child had hydranencephaly and was bedridden with spastic paraplegia needing admissions for shunt infection and revision. Of the two cases of hydrocephalus one had arrested hydrocephalus. This infant had initial mild motor delay but was growing well and was discharged from follow up at 4 years of age.

Out of seven antenatally diagnosed cases of ACC, 5 were postnatally confirmed by cranial ultrasound and only one needed MRI. Table 3 shows the associated anomalies with classified cases of the ACC and their follow up.

Three cases of cerebellar lesions with gap in the inferior vermis were detected in antenatal US. Two of them had normal postnatal scans and normal development, while one infant was diagnosed to have multisystem involvement. His postnatal US showed periventricular calcifications and were confirmed as congenital rubella syndrome by serology.

There were six cases of posterior fossa cysts; of which arachnoid cyst was diagnosed in five of them and one of them was Dandy-Walker malformation. One of the prenatal US diagnosed arachnoid cyst had a large (19mm) cisterna magna. An MRI done at 6 months age for delayed development showed absent vermis and diagnosed as Dandy walker variant. Geneticist suspected Joubert syndrome in this infant but parents refused further confirmatory tests.

One case of cerebral tumor was diagnosed at 36 weeks. The tumor measured $94 \mathrm{~mm}$ in length, $93 \mathrm{~mm}$ in breadth and $86 \mathrm{~mm}$ in width. The screening scan done at 20 weeks was normal but 36 week US scan revealed a tumor mass. Postnatal CT scan showed a large central intraventricular contrast-enhancing tumor containing cystic areas and calcification.

The Alpha-fetoprotein level was highly elevated at $304687 \mathrm{ug} / \mathrm{L}$ and suspected an intracranial germ cell tumor. The infant died at 37 days old prior to any surgical intervention.

Infant who had porencephalic cyst had hemiplegia. This child was last seen at 8 years of age with right hemiparesis and he was attending normal school. The child with a hypoechoic lesion in the right cerebral area had multisystem involvement and was suspected to have cerebro-oculo-facio-skeletal syndrome (COFS).

There were total of 5(17\%) deaths, 2 in infancy, one with trosmy18 and one with the cerebral tumor. The child with suspected COFS died at 2 years, the boy with semi lobar holoprosencephaly died at 9yrs of age and the child with Dandy-Walker syndrome died at 5.5 years of age. 
Table- 3: Classified cases of the agenesis of the corpus callosum (ACC) and their associated anomalies

\begin{tabular}{|c|c|c|c|c|c|c|}
\hline S/No & $\begin{array}{l}\text { Gestational } \\
\text { age at } \\
\text { diagnosis } \\
\text { (weeks) }\end{array}$ & Antenatal finding & $\begin{array}{c}\text { Other } \\
\text { anomalies }\end{array}$ & Postnatal findings & Karyotype & Outcome \\
\hline 1 & 34 & $\begin{array}{l}\text { Agenesis of corpus } \\
\text { callosum. } \\
\text { Dilatation of } \\
\text { posterior horn of } \\
\text { lateral ventricles. }\end{array}$ & - & $\begin{array}{l}\text { Agenesis of corpus } \\
\text { callosum. Some } \\
\text { dilatation of } \\
\text { posterior horn of } \\
\text { lateral ventricles } \\
\text { noted. }\end{array}$ & Not done & $\begin{array}{l}\text { Last seen at } 1 \\
\text { year, normal } \\
\text { development, } \\
\text { defaulted on } \\
\text { follow-ups. }\end{array}$ \\
\hline 2 & 28 & $\begin{array}{l}\text { Absent corpus } \\
\text { callosum. Septo-optic } \\
\text { dysplasia. Dilated } \\
\text { third ventricle }\end{array}$ & \begin{tabular}{|c|} 
Small heart, \\
ventricular septal \\
defect. Short \\
nasal bone. \\
Echogenic \\
bowel.
\end{tabular} & $\begin{array}{l}\text { Dysplastic corpus } \\
\text { callosum, absent } \\
\text { cavum septum } \\
\text { pellucidum. }\end{array}$ & Trisomy18 & $\begin{array}{c}\text { Died at } 24 \text { days } \\
\text { old. }\end{array}$ \\
\hline 3 & 20 & $\begin{array}{l}\text { Corpus callosum not } \\
\text { clearly seen, MRI } \\
\text { confirmed absent } \\
\text { corpus callosum }\end{array}$ & - & $\begin{array}{l}\text { Absent corpus } \\
\text { callosum. }\end{array}$ & Not done & $\begin{array}{c}\text { Last seen at } 4 \mathrm{yrs} \\
\text { of age old, with } \\
\text { normal } \\
\text { development. }\end{array}$ \\
\hline 4 & 20 & $\begin{array}{l}\text { Absent corpus } \\
\text { callosum. } \\
\text { Mild dilated third } \\
\text { ventricle }\end{array}$ & & $\begin{array}{l}\text { Absent corpus } \\
\text { callosum }\end{array}$ & $46 X Y$ & $\begin{array}{l}\text { Mild hypotonia } \\
\text { at 3yrs old. } \\
\text { Development } \\
\text { normal at } 4 \text { yrs } \\
\text { old - discharged. }\end{array}$ \\
\hline 5 & 26 & $\begin{array}{l}\text { Absent cavum } \\
\text { septum pellucidum. } \\
\text { corpus callosum } \\
\text { absent }\end{array}$ & - & $\begin{array}{l}\text { Absent septum } \\
\text { pellucidum. Corpus } \\
\text { callosum seen, } \\
\text { heterotopic grey } \\
\text { matter seen in } \\
\text { parietal and } \\
\text { perisyvlian areas. }\end{array}$ & Not done & $\begin{array}{c}\text { Last seen at } 2 \text { yrs } \\
\text { old. Normal } \\
\text { development }\end{array}$ \\
\hline 6 & 31 & $\begin{array}{c}\text { Absent corpus } \\
\text { callosum. } \\
\text { Gap seen in inferior } \\
\text { cerebellum. Ventricul } \\
\text { omegaly }\end{array}$ & - & $\begin{array}{l}\text { Corpus callosum } \\
\text { well seen. } \\
\text { Ventriculomegaly } \\
\text { PVL on MRI at } 2 \\
\text { years. }\end{array}$ & Not done & $\begin{array}{c}\text { Last seen } 4.5 \\
\text { years old. Mild } \\
\text { to moderate } \\
\text { motor delay and } \\
\text { expressive } \\
\text { language delay. }\end{array}$ \\
\hline 7 & 28 & $\begin{array}{l}\text { Agenesis of corpus } \\
\text { callosum }\end{array}$ & - & $\begin{array}{l}\text { Agenesis of corpus } \\
\text { callosum. }\end{array}$ & Not done & $\begin{array}{l}\text { Normal growth. } \\
\text { Last seen at } 3 \\
\text { years old. }\end{array}$ \\
\hline
\end{tabular}

\section{Discussion}

Central nervous system (CNS) malformations are the second most common cause of congenital anomaly, after congenital heart disease. These malformations pose a difficult challenge to the clinician with regards to diagnosis and management.

This study has brought to light the major CNS defects that have lasting consequences in the infant's life. A study conducted by Tan $\mathrm{K} \mathrm{H}$ et al. showed that the incidence of birth defects was 15.13 per 1,000 live births with 95\% (CI 14.0-16.2) and CNS defect was 1.16 per 1,000 live births with $95 \%$ (CI 0.87-1.52) in Singapore [16].
The most common antenatal CNS anomaly our study found was anencephaly. Anencephaly was detected in 43/116 (37\%) with six live births (included). Anencephaly is the most severe and lethal malformation among congenital defects [17]. A study by Johnson CY et al. showed that $83 \%$ of pregnancies range, (31-97\%) affected with anencephaly and $63 \%$ of pregnancies known to be affected with spina bifida range, (31-97\%) end in termination of pregnancy [18]. These figures coincide with our findings. Thirty-seven $(88 \%)$ among 43 cases of anencephaly underwent TOP and $85 \%$ of neural tube defect had abortion/TOP. 4 out of 7 (57\%) cases of holoprosencephaly in the terminated group had 
chromosomal abnormalities and major associated malformations. Chromosomal abnormalities were found in $65.9 \%$ of fetuses with holoprosencephaly, in a study by Kagan KO et al. [19].

ACC seen in $50 \%$ of the cases in the TOP and fetal death group had major associated malformations. Only two karyotyping done in this group and on turned out to be trisomy 18. Although karyotyping was offered, many parents refused to do prenatal tests.

The post-mortem take-up rate is traditionally low in many countries as shown by our study too. Although the numbers are low, postmortem studies had good correlation with the ultrasound findings. There is evidence showing the value of fetal post-mortem in establishing the etiology of congenital anomalies [20, 21]. A study by Rodriguez MA et al found that the detection rates were highest for CNS malformations $(91.5 \%)$ following autopsy [22].

It is well known that the fetal US has limited specificity, in the diagnoses of posterior fossa anomalies [23]. Fetal MRI allows direct visualization of structures in the midline in the sagittal plane, which occurs with abnormalities of the posterior fossa or the corpus callosum [24]. Fetal MRI played a vital role in the diagnosis of porencephalic cyst, schizencephaly and cerebellar lesions in this study cohort. When available, fetal MRI is indicated, allowing confirmation of the finding and assessment of coexisting brain abnormalities in selected cases as shown in our study.

Of the 30 infants who were followed up, the study has shown clearly that major malformations had impact with major morbidity resulting in poor quality of life. Only 9 infants in the cohort underwent neurosurgical procedures. But four children had multiple admissions for shunt blockage and infections.

Neural tube defects remain one of the most dreaded CNS anomalies. Although folic acid supplementation reduces the incidence of neural tube defects, failure in periconceptual intake of folate remains the main cause of neural tube defects, as most pregnancies are unplanned. More work needs to be done in terms of counseling adolescent and married women who are planning pregnancy.

Holoprosencephaly is another major CNS deformity. Among the three infants who were born live, two children had severe GDD. There are wide phenotype variations for these infants, depending on the severity of the lesions. The severe forms are incompatible with life, and genetic counselling for families is recommended. Postnatal karyotype was performed only in one case. In all cases, amniocentesis and cytogenetic studies were offered, but were refused by the parents. While the prognosis of children with Holoprosencephaly is variable, most of them have neurological impairment [25].

Agenesis of the CC (ACC) is a common CNS anomaly with an incidence of 0.5-7 in 10,000 live births [26]. Among the six cases 4 infants with agenesis or dysgenesis of the $\mathrm{CC}$, had normal growth and development. Many studies have shown that ACC is associated with a number of CNS abnormalities and syndromes, as well as chromosomal anomalies where the outcome is poor. The prospective risk of neurodevelopmental delay for a fetus with ACC isolated prenatally is $27 \%$, compared with $15 \%$ for an infant whose diagnosis of isolated ACC is confirmed postnatally [27]. The fetal MRI is indicated to supplement the findings provided by ultrasound because it allows precise visualization and understanding of the extent and severity of anomalies [28, 29]. Families of infants diagnosed with ACC should be offered genetic counselling and these infants need long-term follow-up by a multidisciplinary team to assess their development and to address other comorbidities like epilepsy and feeding problems. The limitation of our study is that these infants who were considered normal were either discharged early or lost to follow up.

Dandy-walker malformation is associated with a high chance of poor prognosis [30]. Outcome data remains conflicting in these children. However, there appears to be a higher association with better neurodevelopmental outcome when a normally lobulated vermis is present, and when associated CNS anomalies are absent [31].

Unfortunately, the two cases of schizencephaly were diagnosed late in the third trimester due to social reasons. The infants ended up bedridden with severe GDD. Both were born to young mothers: one was 16 and the other 23 years old. Only one mother underwent a fetal MRI. Schizencephaly is rare, with most of cases still recognized only after birth, with increased frequency in younger mothers, and in association with other conditions arising from vascular disruption [32]. The California Birth Defects Monitoring program found that schizencephaly occurred in one every 70,000 live born children and that only one of 63 cases was 
suspected antenatally [33]. A survey done on schizencephaly showed that the severity of the motor and mental impairments is directly related to the extent of the anatomic defect [34].

In our study the surviving children with severe malformations were moderately or severely disabled. Some mothers had screening scan late in pregnancy. As per our ethical guidelines, abortion is not allowed after 24 weeks, unless the malformation is proved to be lethal. Our study shows that prenatal diagnosis of CNS malformations is mandatory to prevent major morbidity and the prognosis can be estimated early enough to act on.

Limitations-Given the large number of heterogeneous cases in our cohort, our data is not sufficiently powered to give targeted reports. Some infants who were considered normal were either discharged early or the parents discontinued follow-ups.

The brain anomalies may have effect on learning, writing, emotional changes etc. The infants require regular follow-ups by the pediatrician till they are at least 10 years old. Most of the cases of neurodisability were followed up for early intervention by a multidisciplinary team including, occupational therapist, physiotherapist, and neurologist.

This study also highlights the importance of fetal MRI and post-mortem studies. As the numbers were less in our study we are unable in this retrospective study to comment on the specificity of fetal MRI. Even if a full autopsy is not performed, cytogenetic studies and/or chromosomal microarray should be recommended at the very least, before the termination of a pregnancy. This procedure will allow as much information to be gathered as possible for postnatal review and counseling.

Acknowledgement: The author would like to thank Sheryl Quek Xianyu and Dayana Eddy for the support given in preparation of the manuscript.

Funding: Nil, Conflict of interest: Nil

Permission from IRB: Yes

\section{References}

1. Rosano A, Botto LD, Botting B, Mastroiacovo P. Infant mortality and congenital anomalies from 1950 to 1994: an international perspective. J Epidemiol Community Health. 2000 Sep;54(9):660-666.
2. Garne E, Dolk H, Loane M, Wellesley D, Barisic I, Calzolari E, Densem J; EUROCAT Working Group. Paper 5: Surveillance of multiple congenital anomalies: implementation of a computer algorithm in European registers for classification of cases. Birth Defects Res A Clin Mol Teratol. 2011 Mar; 91 Suppl 1:S 44-50

3. Decouflé P,Boyle CA, Paulozzi LJ, Lary JM. Increased Risk for Developmental Disabilities in Children Who Have Major Birth Defects: A PopulationBased Study. Pediatrics. 2001 Sep;108(3):728-734.

4. Limb CJ, Holmes LB. Anencephaly: changes in prenatal detection and birth status, 1972 through 1990. Am J Obstet Gynecol.1994 May;170: 1333-1338.

5. Grandjean H, Larroque D, Levi S. Eurofetus Study Group.The performance of routine ultrasonographic screening of pregnancies in the Eurofetus Study. Am J Obstet Gynecol.1999; 181(2): 446-454.

6. Mighell AS, Johnstone ED, Levene M. Post-natal investigations: management and prognosis for fetuses with CNS anomalies identified in utero excluding neurosurgical problems. Prenat Diagn. 2009 Apr; 29 (4):442-449.

7. Leitner Y, Goez H, Gull , Mesterman R, Weiner E, Jaffa A, Harel S Antenatal diagnosis of central nervous system anomalies: can we predict prognosis? J Child Neurol. 2004 Jun;19(6):435-8.

8. Ben Sira L, Garel C, Leitner Y, Gross-TsurV. Prenatal imaging of the fetal brain - indications and developmental implications of fetal MRI. Harefuah. 2008; 147(1):65-70.

9. Whitlow BJ, Chatzipapas IK, Lazanakis ML, Kadir RA, Economides DL. The value of sonography in early pregnancy for the detection of fetal abnormalities in an unselected population.Br J Obstet Gynaecol. 1999; 106 (9): 929-936.

10. Manchester DK, Pretorius DH, Avery C, MancoJohnson ML, Wiggins J, Meier PR, Clewell WH. Accuracy of ultrasound diagnoses in pregnancies complicated by suspected fetal anomalies.Prenat Diagn. 1988 Feb;8(2):109-117.

11. Chung R, Kasprian G, Brugger PC, Prayer D. The current state and future of fetal imaging. Clin Perinatol 2009;36(3):685-699. 
12. Glenn OA, Barkovich J. Magnetic resonance imaging of the fetal brain and spine: an increasingly important tool in prenatal diagnosis: Part 2. AJNR Am J Neuroradiol. 2006 Oct;27(9):1807-1814.

13. Ozkan ZS, Gilgin H, Aygün HB, Deveci D, Simşek M, Kumru S, Yüce H. Our clinical experience about prenatal diagnosis and neonatal outcomes of fetal central nervous system anomalies. J Matern Fetal Neonatal Med. 2011 Mar;24(3):502-505.

14. Adama van Scheltema PN, Nagel HT, et al. Outcome of children with prenatally diagnosed central nervous system malformations. Ultrasound Obstet Gynecol. 2003; 21(1):41-47.

15. Li Y, Sansgiri RK, Estroff JA, et al. Outcome of foetuses with cerebral ventriculomegaly and septum pellucidum leaflet abnormalities. AJR Am J Roentgenol 2011; 196(1):W83-92.

16. K H Tan, T Y T Tan, J Tan, I Tan, S K Chew, G S H Yeo Birth defects in Singapore: 1994-2000 Singapore Med J 2005; 46(10) : 545 -552.

17. Johnson SP, Sebire NJ, Snijders RJ, Tunkel S, Nicolaides KH. Ultrasound screening for anencephaly at 10-14 weeks of gestation. Ultrasound Obstet Gynecol 1997;9(1):14-16.

18. Johnson CY, Honein MA, Dana Flanders W, Howards PP, Oakley GP Jr, Rasmussen SA.Pregnancy termination following prenatal diagnosis of anencephaly or spina bifida: A systematic review of the literature Birth Defects Res A Clin Mol Teratol. 2012 Nov;94(11):857-863.

19. Kagan KO, Staboulidou I, Syngelaki A, Cruz J, Nicolaides KH. The 11-13-week scan: diagnosis and outcome of holoprosencephaly, exomphalos and megacystis. Ultrasound Obstet Gynecol. 2010 Jul; 36 (1):10-14.

20. Clayton-Smith J, Farndon PA, McKeown C, Donnai D. Examination of fetuses after induced abortion for fetal abnormality. BMJ. 1990; Feb 3; 300 (6720): 295-297.

21. Boyd PA, Tondi F, Hicks NR, Chamberlain PF. Autopsy after termination of pregnancy for fetal anomaly: retrospective cohort study. BMJ. 2004 Jan 17;328(7432):137-140.
22. Rodriguez MA, Prats P, Rodríguez I, Cusí V, Comas C. Concordance between prenatal ultrasound and autopsy findings in a tertiary center. Prenat Diagn. 2014 Aug;34(8):784-789.

23. Whitby EH, Paley MN, Sprigg A, Rutter S, Davies NP, Wilkinson ID, Griffiths PD. Comparison of ultrasound and magnetic resonance imaging in 100 singleton pregnancies with suspected brain abnormalities. BJOG. 2004 Aug; 111(8): $784-92$.

24. Herman-Sucharska I, Bekiesińska-Figatowska M, Urbanik A. Fetal central nervous system malformations on MR images. Brain Dev 2009; 31(3):185-199.

25. Pilu G, Sandri F, Perolo A, Giangaspero F, Cocchi G, Salvioli GP, Bovicelli L Prenatal diagnosis of lobar holoprosencephaly. Ultrasound Obstet Gynecol. 1992; Mar 1; 2(2):88-94..

26. Hosseinzadeh K, Luo J, Borhani A, Hill L. Nonvisualisation of cavum septi pellucidi: implication in prenatal diagnosis?. Insights Imaging. 2013 Jun;4 (3):357-367.

27. Mangione $\mathrm{R}$, Fries $\mathrm{N}$, Godard $\mathrm{P}$, et al. Neurodevelopmental outcome following prenatal diagnosis of an isolated anomaly of the corpus callosum. Ultrasound Obstet Gynecol 2011; 37(3): 290-295.

28. Rossi AC, Prefumo F. Additional value of fetal magnetic resonance imaging in the prenatal diagnosis of central nervous system anomalies: a systematic review of the literature. Ultrasound Obstet Gynecol 2014;Oct; 44(4):388-393.

29. Patenaude Y, Pugash D, Lim K, et al. The use of magnetic resonance imaging in the obstetric patient. SOGC Clinical Practice Guidelines, No. 306, April 2014. J Obstet Gynaecol Can 2014;36(4):349-63.

30. Forzano F, Mansour S, Ierullo A, Homfray T, Thilaganathan B. Posterior fossa malformation in fetuses: a report of 56 further cases and a review of the literature. PrenatDiagn.2007; 27(6): 495-501.

31. Klein O, Pierre-Kahn A, Boddaert N, Parisot D, Brunelle F.Dandy-Walker malformation: prenatal diagnosis and prognosis. Childs Nerv Syst. 2003;19 (7-8):484-489. 
32. Howe DT, Rankin J, Draper ES.Schizencephaly prevalence, prenatal diagnosis and cluesto etiology: a register-based study. Ultrasound Obstet Gynecol 2012; 39 (1): 75-82.

33. Curry CJ, Lammer EJ, Nelson V, Shaw GM. Schizencephaly: heterogeneous etiologies in a population of 4 million California births. Am J Med Genet A 2005; 137(2): 181-189.

34. Oh KY, Kennedy AM, Frias AE Jr, Byrne JL. Fetal schizencephaly: pre- and postnatal imaging with a review of the clinical manifestations. Radiographics. 2005; 25(3):647-657.

\section{How to cite this article?}

Geetha O, Chandran S, Sriram B, George Y. S. H, Gomez J. M, Rajadurai V. S. Outcome of prenatally diagnosed central nervous system malformations in a tertiary center in Singapore. Int J Pediatr Res.2016;3(8):557566.doi:10.17511/ijpr.2016.i08.03 